\title{
Venom complexity of Bothrops atrox (common lancehead) siblings
}

\author{
Daniela Miki Hatakeyama ${ }^{1,2}$, Lídia Jorge Tasima ${ }^{1,2}$, Cesar Adolfo Bravo-Tobar ${ }^{1,2}$, Caroline Serino-Silva ${ }^{1,2}$, \\ Alexandre Keiji Tashima ${ }^{3}$ (D), Caroline Fabri Bittencourt Rodrigues, ${ }^{1,2}$, Weslei da Silva Aguiar ${ }^{1,2}$, Nathália da Costa \\ Galizio $^{1,2}$, Eduardo Oliveira Venancio de Lima1, Victor Koiti Kavazoi, ${ }^{1,2}$, Juan David Gutierrez-Marín ${ }^{1,2}$, \\ lasmim Baptista de Farias ${ }^{1,2}$, Sávio Stefanini Sant'Anna ${ }^{1}$, Kathleen Fernandes Grego ${ }^{1}$ (D), Karen de Morais-Zani ${ }^{1,2}$ (D), \\ Anita Mitico Tanaka-Azevedo ${ }^{1,2 *}$ (D) \\ ${ }^{1}$ Laboratory of Herpetology, Butantan Institute, São Paulo, SP, Brazil. \\ ${ }^{2}$ Interinstitutional Graduate Program in Biotechnology (IPT, IBU and USP), University of São Paulo (USP), São Paulo, SP, Brazil. \\ ${ }^{3}$ Department of Biochemistry, Federal University of São Paulo (Unifesp), São Paulo, SP, Brazil.
}

\section{Keywords:}

Bothrops atrox

Snake venom

Individual variation

Envenomation

\begin{abstract}
Background: Variability in snake venoms is a well-studied phenomenon. However, sex-based variation of Bothrops atrox snake venom using siblings is poorly investigated. Bothrops atrox is responsible for the majority of snakebite accidents in the Brazilian Amazon region. Differences in the venom composition of Bothrops genus have been linked to several factors such as ontogeny, geographical distribution, prey preferences and sex. Thus, in the current study, venom samples of Bothrops atrox male and female siblings were analyzed in order to compare their biochemical and biological characteristics.

Methods: Venoms were collected from five females and four males born from a snake captured from the wild in São Bento (Maranhão, Brazil), and kept in the Laboratory of Herpetology of Butantan Intitute. The venoms were analyzed individually and as a pool of each gender. The assays consisted in protein quantification, 1-DE, mass spectrometry, proteolytic, phospholipase $\mathrm{A}_{2}$, L-amino acid oxidase activities, minimum coagulant dose upon plasma, minimum hemorrhagic dose and lethal dose $50 \%$.

Results: Electrophoretic profiles of male's and female's venom pools were quite similar, with minor sex-based variation. Male venom showed higher LAAO, PLA and hemorrhagic activities, while female venom showed higher coagulant activity. On the other hand, the proteolytic activities did not show statistical differences between pools, although some individual variations were observed. Meanwhile, proteomic profile revealed 112 different protein compounds; of which 105 were common proteins of female's and male's venom pools and seven were unique to females. Despite individual variations, lethality of both pools showed similar values.

Conclusion: Although differences between female and male venoms were observed, our results show that individual variations are significant even between siblings, highlighting that biological activities of venoms and its composition are influenced by other factors beyond gender.
\end{abstract}

\footnotetext{
* Correspondence: anita.azevedo@butantan.gov.br https://doi.org/10.1590/1678-9199-JVATITD-2020-0018 


\section{Background}

Snakebite envenomation is considered a worldwide Category A neglected tropical disease and constitutes a public health problem in warmer regions of the developing world $[1,2]$. In Latin America, the family Viperidae is responsible for most of the registered snakebite accidents, and in Brazil, the genus Bothrops is responsible for $85 \%$ of the ophidian envenomation [1-5].

Bothrops atrox (common lancehead) is a pit viper species widely distributed in the northern region of South America [7-9] and its natural history is already well documented [10]. This generalist species occurs mostly in rainforests, but can also be found in disturbed areas. In relation to other Bothrops species, the common lancehead shows preference towards heavier preys [11]. Males are smaller than females and are more prone to higher mortality, considering the active foraging lifestyle of the species. In fact, B. atrox exhibits a dynamic use of its habitat, being known as one of the most active hunters of the Bothrops genus $[9,11,12]$. B. atrox venom causes mainly local damage, such as edema, hemorrhage and necrosis, apart from systemic effects, including blood coagulation disorders $[13,14]$. In lethal cases, hemorrhage leads to cardiovascular shock and acute renal failure secondary to acute tubular necrosis and occasionally glomerulonephritis $[7,15]$. These symptoms are the result of individual or synergistic action of different toxins that comprise the venom of snakes $[16,17]$, such as phospholipases $\mathrm{A}_{2}$ ( $\mathrm{PLA}_{2} \mathrm{~s}$ ), metalloproteinases (SVMPs), serine proteinases (SVSPs), L-amino acid oxidases (LAAOs), among others $[1,18]$. The knowledge about the composition and action of snake venoms allows us to understand the evolutionary processes in ophidians [19] and elucidate the mode of action of toxins and the demand for their antagonists [20]. In addition, as snake venoms are a rich source of bioactive compounds with pharmaceutical potential, they can represent an improvement in snakebite envenoming treatment, which can impact significantly on the victims symptoms and the quality and efficacy of antivenoms $[21,22]$.

Individual variability is a well-established concept when referring to intraspecific variation of snake venom composition and/or its activities, and may be related to ontogeny [23-25], diet [26,27], seasonality [28], geographical location [29-31], gender [32-35], and captivity [22,36]. Within the Bothrops species, $B$. jararaca venom is the most studied one regarding gender differences [32,37], contrary from B. atrox, despite its high geographic distribution and epidemiological representation. In this context, the present study aims to compare, for the first time, the biochemical and biological characteristics of male and female venom of $B$. atrox siblings. Both genders were born in captivity and maintained under controlled conditions, in order to contribute to the knowledge of changes in venom characteristics according to sex, as well as the formulation of pharmacological tools for inhibiting the toxic effects of this venom.

\section{Methods}

\section{Animals}

Mus musculus (Swiss) male mice (18-22 g) were obtained from Butantan Institute animal house, had access to water and food ad libitum and were kept under a $12 \mathrm{~h}$ light/dark cycle. B. atrox specimens ( 5 females and 4 males over 11 years of age) (Additional file 1) were born from the same snake captured from the wild (São Bento, Maranhão, Brazil), and kept in the Laboratory of Herpetology of Butantan Institute under controlled conditions.

\section{Venoms}

The venom was extracted from nine $B$. atrox snakes ( 5 females and 4 males born from the same mother), centrifuged for $15 \mathrm{~min}$ at $1700 \times g, 4^{\circ} \mathrm{C}$, to remove any scales or mucus, lyophilized, and stored at $-20^{\circ} \mathrm{C}$ until use. Information regarding the snakes is available in Additional file 1.

\section{Compositional analysis}

\section{Protein quantification}

Protein concentration of pools (female and male) and individual venom samples was determined according to the Bradford method, using Bio-Rad Protein Assay reagent and bovine serum albumin (BSA) (Sigma) as standard [38]. These data were only used as a basis to other experiments.

\section{One-dimensional electrophoresis (1-DE)}

Electrophoretic analysis of pools and individual venom samples was performed using $30 \mu \mathrm{g}$ of protein in the presence and absence of $\beta$-mercaptoethanol in $15 \%$ polyacrylamide gels [39]. The gels were stained with Coomassie Blue G according to the GE Healthcare protocol.

\section{Protein identification by mass spectrometry}

Identification of proteins was performed by LC-MS/MS in a Synapt G2 (Waters) coupled to the nanoAcquity UPLC chromatographic system (Waters) as previously described [40,41]. Briefly, samples of $100 \mu \mathrm{g}$ of protein from each venom pool were incubated in $50 \mathrm{mM}$ ammonium bicarbonate with $5 \mathrm{mM}$ DTT (dithiothreitol) for $25 \mathrm{~min}$ at room temperature (RT), followed by addition of $14 \mathrm{mM}$ IAA (iodoacetamide) and incubation in the dark for $30 \mathrm{~min}$ at RT. Finally, an incubation with $5 \mathrm{mM}$ DTT for 15 min was performed. Calcium chloride $(1 \mathrm{mM})$ and $1 \mu \mathrm{g}$ of trypsin (Sigma) in $50 \mathrm{mM}$ ammonium bicarbonate were added to each sample and incubated for $16 \mathrm{~h}$ at $37^{\circ} \mathrm{C}$. After incubation, the reaction was stopped with 5\% TFA (0.5\% final concentration). Aliquots of the resulting peptide mixtures $(5 \mu \mathrm{g})$ were injected into a trap column packed with $\mathrm{C} 18$ (nanoAcquity trap Symmetry $180 \mu \mathrm{m} \times 20 \mathrm{~mm}$ ) at $8 \mu \mathrm{L} / \mathrm{min}$ with phase $\mathrm{A}$ $(0.1 \%$ formic acid. Peptides were then eluted onto an analytical C18 column (nanoAcquity BEH $75 \mu \mathrm{m} \times 200 \mathrm{~mm}, 1.7 \mathrm{~m}$ ) at a flow rate of $275 \mathrm{~nL} / \mathrm{min}$, using a gradient of $7-35 \%$ of phase $B$ 
$(0.1 \%$ formic acid in acetonitrile) in $90 \mathrm{~min}$. Data were acquired in the in data-independent mode UDMSE [42] in the $\mathrm{m} / \mathrm{z}$ range of 50-2000 and in resolution mode. Collision energies were alternated between $4 \mathrm{eV}$ and a ramp of $17-60 \mathrm{eV}$ for precursor ion and fragment ions, respectively, using scan times of $1.25 \mathrm{~s}$. The ESI source was operated in positive mode with a capillary voltage of $3.0 \mathrm{kV}$, block temperature of $70^{\circ} \mathrm{C}$, and cone voltage of $40 \mathrm{~V}$. For lock mass correction, [Glu1]-Fibrinopeptide B solution $(500 \mathrm{fmol} / \mathrm{mL}$ in $50 \%$ acetonitrile, $0.1 \%$ formic acid; Peptide 2.0) was infused through the reference sprayer at 500 $\mathrm{nL} / \mathrm{min}$ and sampled for $0.5 \mathrm{~s}$ at each $60 \mathrm{~s}$.

Raw data were processed in ProteinLynx Global Server 3.0.1 (Waters) by the Apex3D module using low energy threshold of 750 counts and elevated energy threshold of 50 counts. MS/ MS spectra were submitted to searches a Serpentes database (downloaded from Uniprot in March 1 ${ }^{\text {st }}, 2019,2608$ reviewed sequences). The following search parameters were used: automatic fragment and peptide mass tolerances, carbamidomethylation of cysteines as fixed modification, oxidation of methionine, $\mathrm{N}$-terminal acetylation, glutamine and asparagine deamidation as variable modifications, up to 2 missed cleavage sites were allowed for trypsin digestion. The following criteria were set for protein identification: a minimum of 1 fragment ion per peptide, 5 fragment ions per protein and 2 peptides per protein, and a maximum false discovery identification rate of $1 \%$, estimated by a simultaneous search against a reversed database. Label-free quantitative assessments were based on the average intensities of the three most intense peptides of each identified protein [43]. Each pooled sample was analyzed in technical triplicate. Data of the spectra are available in Additional file 2.

\section{Enzymatic activities}

\section{Caseinolytic activity}

Caseinolytic activity was determined as described [44] using azocasein (Merck) as substrate. Briefly, $85 \mu \mathrm{L}$ of a $4.25 \mathrm{mg} / \mathrm{mL}$ azocasein solution were incubated with $10 \mu \mathrm{L}$ of each venom (1 $\mathrm{mg} / \mathrm{mL}$ ), both diluted in $50 \mathrm{mM}$ Tris- $\mathrm{HCl}$ buffer, $\mathrm{pH}$ 8.0. The reaction was stopped by adding $200 \mu \mathrm{L}$ of $5 \%$ trichloroacetic acid (TCA). The samples were centrifuged at $1000 \times \mathrm{g}$ and $100 \mu \mathrm{L}$ of the supernatant were homogenized with $100 \mu \mathrm{L}$ of $0.5 \mathrm{M} \mathrm{NaOH}$. The absorbance was measured at $450 \mathrm{~nm}$ in a SpectraMax i3 microplate reader (Molecular Devices). One unit of activity was determined as the amount of venom that induces an increase of 0.005 units of absorbance.

\section{Collagenolytic activity}

Collagenolytic activity over azocoll was determined according to Váchová and Moravcová [45] and modified by Antunes et al. [46]. Venoms $(6.25 \mu \mathrm{g})$ were incubated with $50 \mu \mathrm{L}$ of a $5 \mathrm{mg} /$ $\mathrm{mL}$ azocoll (Sigma) solution, both diluted in Tyrode buffer (137 $\mathrm{mM} \mathrm{NaCl}, 2.7 \mathrm{mM} \mathrm{KCl}, 3 \mathrm{mM} \mathrm{NaH} \mathrm{PO}_{4}, 10 \mathrm{mM}$ HEPES, 5.6 $\mathrm{mM}$ dextrose, $1 \mathrm{mM} \mathrm{MgCl}_{2}, 2 \mathrm{mM} \mathrm{CaCl}_{2}, \mathrm{pH}$ 7.4) for $1 \mathrm{~h}$ in constant shake, at $37^{\circ} \mathrm{C}$. The samples were centrifuged for $3 \mathrm{~min}$ at $5000 \times \mathrm{g}$ and the absorbance of the supernatants $(200 \mu \mathrm{L})$ was measured at $540 \mathrm{~nm}$ in a SpectraMax i3 microplate reader (Molecular Devices). One unit of activity was determined as the amount of venom that induces an increase of 0.003 units of absorbance.

\section{L-amino acid oxidase activity}

Pools and individual venom samples were analyzed by measuring the hydrogen peroxide generated during the oxidation of L-amino acids [47]. For this, $5 \mu \mathrm{g}$ of the venom were added to the $90 \mu \mathrm{L}$ reaction mixture containing $50 \mathrm{mM}$ Tris- $\mathrm{HCl}, 250$ $\mathrm{mM}$ L-methionine, $\mathrm{pH} 8.0,2 \mathrm{mM}$ o-phenylenediamine and 0.8 $\mathrm{U} / \mathrm{mL}$ of horseradish peroxidase, and the mixture incubated at $37{ }^{\circ} \mathrm{C}$ for $60 \mathrm{~min}$. The reaction was stopped using $50 \mu \mathrm{L}$ of $2 \mathrm{M}$ $\mathrm{H}_{2} \mathrm{SO}_{4}$ and the absorbance measured on a spectrophotometer (SpectraMax i3, Molecular Devices) at $492 \mathrm{~nm}$. Results were expressed as $1 \mu \mathrm{M}$ of $\mathrm{H}_{2} \mathrm{O}_{2} /$ minute/ $\mu \mathrm{g}$ of venom.

\section{Phospholipase $A_{2}$ activity}

The phospholipase $\mathrm{A}_{2}\left(\mathrm{PLA}_{2}\right)$ activity of pools and individual venom samples was determined based on the assay developed by Holzer and Mackessy [48] using the monodisperse synthetic substrate 4-nitro-3-octanoyloxy-benzoic acid (NOBA). Twenty $\mu \mathrm{g}$ of venom (dissolved in $0.85 \% \mathrm{NaCl}$ ), $20 \mu \mathrm{L}$ of deionized water and $200 \mu \mathrm{L}$ of $10 \mathrm{mM}$ Tris- $\mathrm{HCl}, 10 \mathrm{mM} \mathrm{CaCl}_{2}, 100 \mathrm{mM} \mathrm{NaCl}, \mathrm{pH}$ 8.0 were mixed in a 96 well microplate. Then, $20 \mu \mathrm{L}$ of NOBA (4.16 $\mathrm{mM}$ in acetonitrile) was added in a final concentration of $0.32 \mathrm{mM}$. After incubating for $20 \mathrm{~min}$ at $37^{\circ} \mathrm{C}$, the absorbance at $425 \mathrm{~nm}$ was recorded in a microplate reader (SpectraMax i3, Molecular Devices). A change of 0.1 absorbance unit at $425 \mathrm{~nm}$ was equivalent to 25.8 nmoles of chromophore release.

\section{Biological functions}

\section{Coagulant activity}

The coagulant activity of the venom pools was assessed in citrated human plasma, according to Theakston and Reid [49]. Briefly, $100 \mu \mathrm{L}$ of plasma were incubated at $37^{\circ} \mathrm{C}$ for $60 \mathrm{~s}$. After the incubation, $50 \mu \mathrm{L}$ of various concentrations of venom samples were mixed and clotting times were measured in a coagulometer (MaxCoag, MEDMAX). The Minimum Coagulant Dose (MCD) was defined as the minimum amount of venom that induced coagulation of plasma in $60 \mathrm{~s}$ at $37^{\circ} \mathrm{C}$.

\section{Hemorrhagic activity}

The hemorrhagic activity was obtained by the determination of Minimum Hemorrhagic Dose (MHD). Groups of five male Swiss mice of $18-22 \mathrm{~g}$ were injected with $100 \mu \mathrm{L}$ of several doses of venom pool samples, diluted in $0.89 \% \mathrm{NaCl}$, intradermally into the venter of the mice, and a control group received $100 \mu \mathrm{L}$ of $\mathrm{NaCl}$ solution under identical conditions. After $3 \mathrm{~h}$, the animals were euthanized in $\mathrm{CO}_{2}$ chamber, the venter skin was removed, and the hemorrhagic areas were measured [50]. The MHD was 
defined as the amount of venom that produced hemorrhages with a mean diameter of $10 \mathrm{~mm}$ after $3 \mathrm{~h}$ [51].

\section{Median lethal dose (LD $\left.{ }_{50}\right)$}

The $\mathrm{LD}_{50}$ of venom pool samples were determined by intraperitoneal injection in 18-22 g male Swiss mice with 500 $\mu \mathrm{L}$ of varying doses of venoms (66-381 $\mu \mathrm{g} / \mathrm{animal})$ in $0.89 \%$ $\mathrm{NaCl}$. Five mice were used per group and the number of deaths occurring within $48 \mathrm{~h}$ after injection was recorded. The $\mathrm{LD}_{50}$ and 95\% confidence intervals were calculated by Probit analysis [52].

\section{Immunorecognition by antibothropic serum}

Individual venoms and pools $(30 \mu \mathrm{L})$ were submitted to $1-\mathrm{DE}$ (15\%) under reducing conditions (as described in the section "One-dimensional electrophoresis (1-DE)") and transferred to PVDF membranes (Bio-Rad) in a semi-dry system (Trans-Blot Turbo Transfer System, Bio-Rad) at $25 \mathrm{~V}$ for $35 \mathrm{~min}$. As described by Harlow and Lane [53], the membranes were blocked with Tris-buffered-saline containing 5\% fat free milk (TBS-milk) overnight at $4{ }^{\circ} \mathrm{C}$. The membranes were incubated with 1:2,000 commercial antibothropic serum (batch 1305077, expiration date due to 2016) for $2 \mathrm{~h}$ at room temperature. After washing with TBS-milk containing $0.1 \%$ Tween 20 , the membranes were exposed to 1:10,000 peroxidase-labelled anti-horse IgG (Sigma) for $2 \mathrm{~h}$ at room temperature. Unbound secondary antibodies were washed off and immunoreactive bands were visualized using diaminobenzidine (Sigma) and $\mathrm{H}_{2} \mathrm{O}_{2}$. The commercial antibothropic serum is produced at Butantan Institute by hyperimmunization of horses using a mixture of five Bothrops species venoms: $B$. jararaca (50\%), B. alternatus (12.5\%), B. jararacussu (12.5\%), B. moojeni (12.5\%) and B. neuwiedi (12.5\%).

\section{Statistical analysis}

Results are expressed as mean \pm SD of triplicates. The significance of differences between the means of the venoms was determined by one-way ANOVA with Tukey as a posteriori test and venom pools were analyzed using Student's $t$-test using GraphPad Prism 7.03 software, where $p<0.05$ was considered significant.

\section{Results and Discussion}

Differences in the composition and activity of snake venoms from the same species are a worldwide researchers concern. These differences can influence directly in the antivenom production and in the success of patient treatment [54-57].

\section{Compositional analysis}

Although B. atrox venom has been analyzed in several aspects [30,58-60], this work showed, for the first time, a comparative study of the venom extracted from female and male siblings, born in captivity and kept under controlled environmental conditions.

Electrophoretic profiles were evaluated, showing similar band patterns with few differences between individuals and pools. Individual analysis of non-reduced venoms showed a common band of $\sim 35 \mathrm{kDa}$ (Figure 1A), which is only present in the venoms of females and of $\mathrm{Ba} 8$ among males, and another band of $\sim 30$ $\mathrm{kDa}$ that is present only in the venom of males, except for $\mathrm{Ba} 8$. These two bands might be associated to P-II SVMP and SVSP respectively, in accordance with their molecular masses [24], and their presence and absence are reflected in the pool, although faint (especially the $\sim 35 \mathrm{kDa}$ band). Moreover, it is possible to observe bands of less intensity between $25-50 \mathrm{kDa}$ (probably CRISP, GPC, P-I and P-III SVMP and SVSP) and over $100 \mathrm{kDa}$ (most likely PDE). These results have been observed not only in B. atrox but also in other snakes of the Bothrops genus, and are supported by several works [31,61-63].

In order to compare the composition of female and male B. atrox venoms, they were pooled according to gender and submitted to in-solution trypsin digestion followed by LC-
A

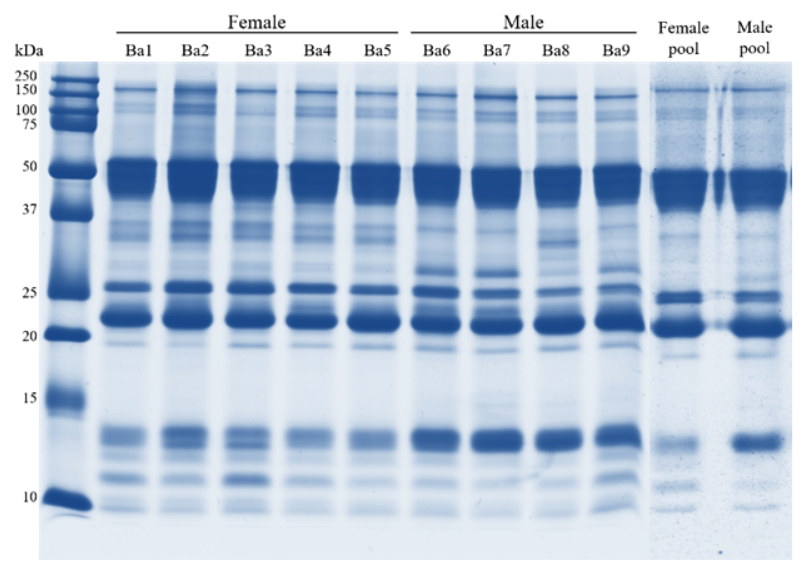

B

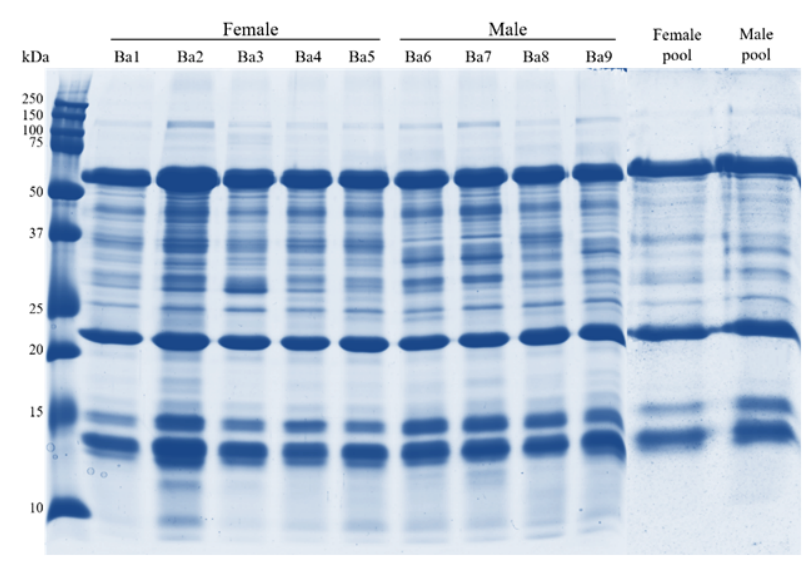

Figure 1. One-dimensional electrophoresis (1-DE) profile of $B$. atrox venoms under (A) non-reducing and (B) reducing conditions. Individual female (Ba1 to $\mathrm{Ba} 5)$, male (Ba6 to $\mathrm{Ba} 9)$ and respective pools were used and are indicated above the gel. 
MS/MS analysis on a Synapt G2 mass spectrometer (Waters). The results obtained allowed to identify 112 different protein compounds (Table 1 and Additional file 3), of which 105 were common proteins between female and male venom pools and 7 were unique to females. Proteins identified belong to the following families: SVMPs, SVSPs, LAAOs, CTLs, PLA 2 , nucleotidase (NT), phospholipase B (PLB), glutaminyl-peptide cyclotransferases (GPCs), cysteine-rich secretory protein (CRISP), and disintegrin-like protein (DISL) (Figure 2, Table 1 and Additional file 3); the first five families are the main
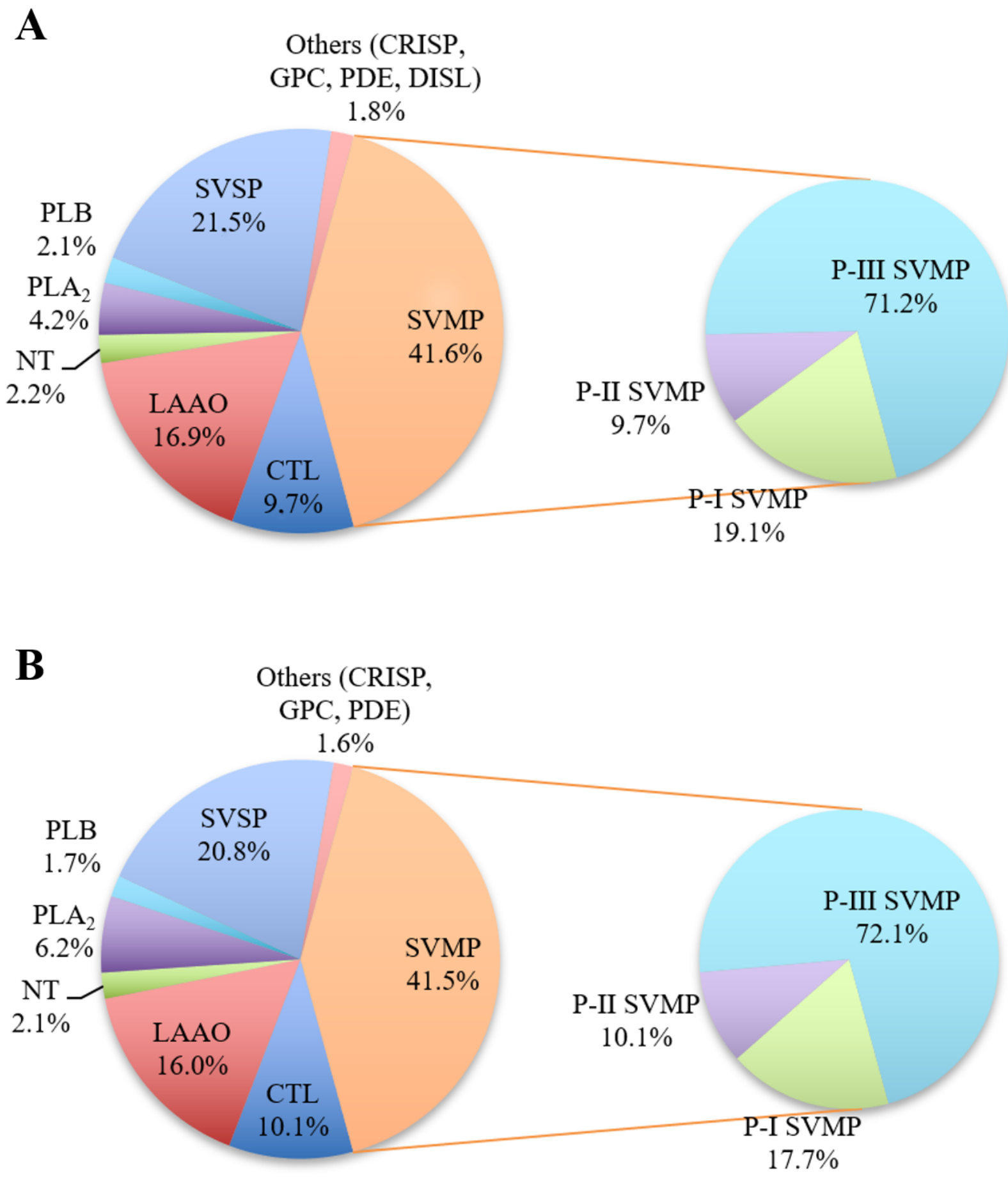

Figure 2. Graphical overview of toxin classes identified in B. atrox (A) female and (B) male venom pools by in nanoESI-qTOF. CRISP: cystein-rich secretory protein; CTL: C-type lectin; DISL: disintegrin-like protein; GPC: glutaminyl-peptide cyclotransferases; LAAO: L-amino acid oxidase; NGF: nerve growth factor; NT: nucleotidase; PDE: phosphodiesterase; PLA: phospholipase $A_{2}$; PLB: phospholipase B; SVMP: snake venom metalloproteinase; SVSP: snake venom serine protease. 


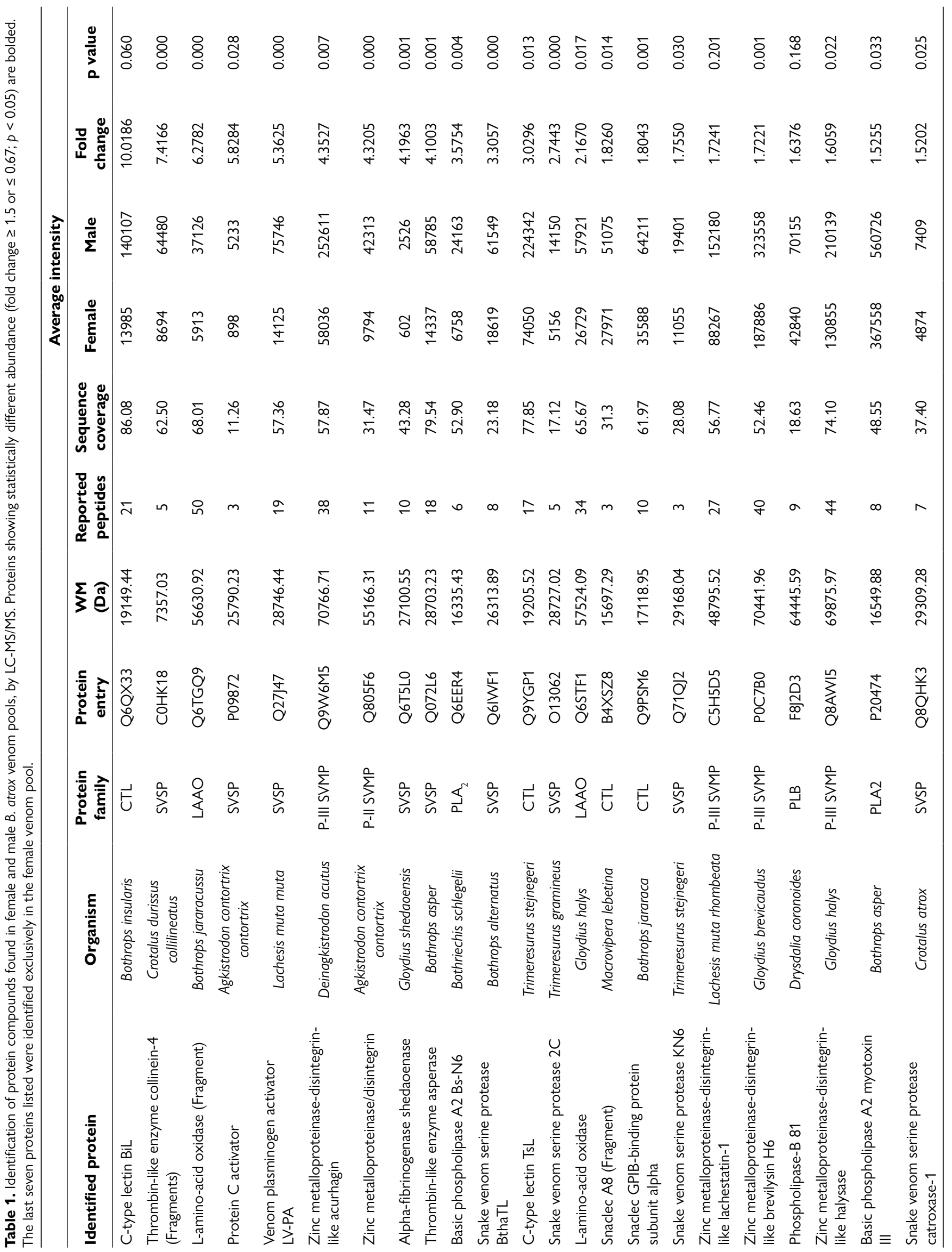




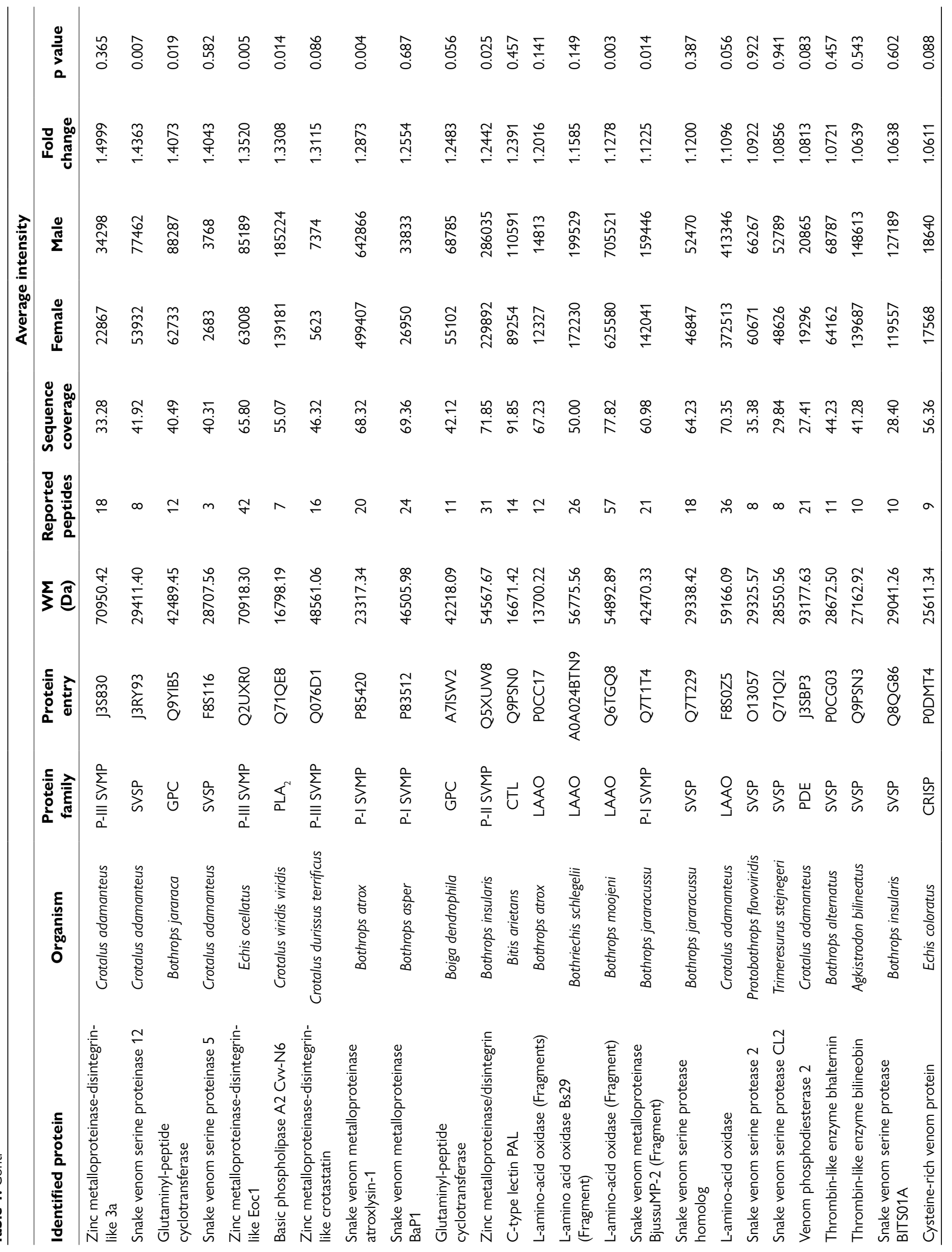




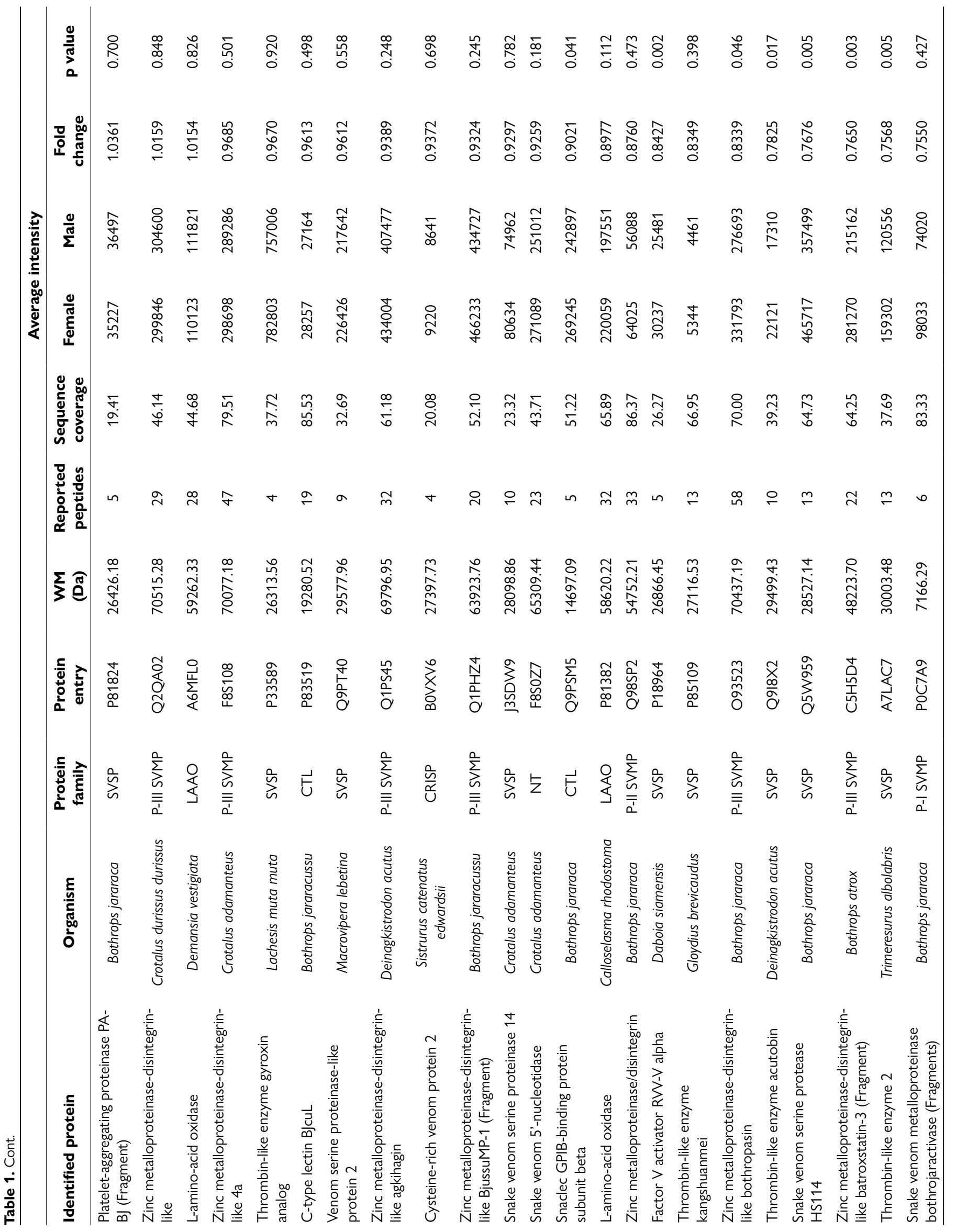




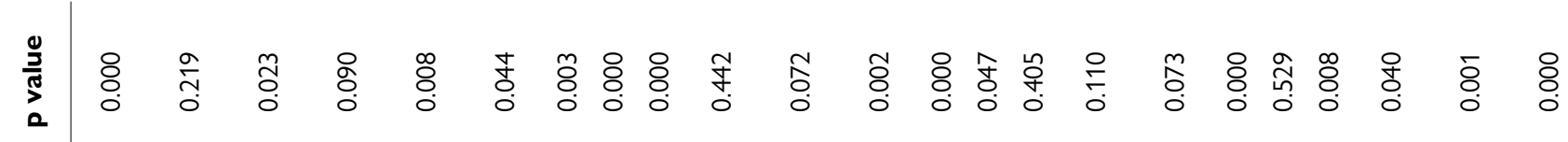

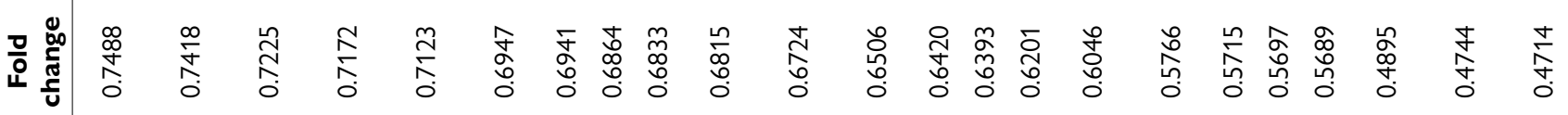

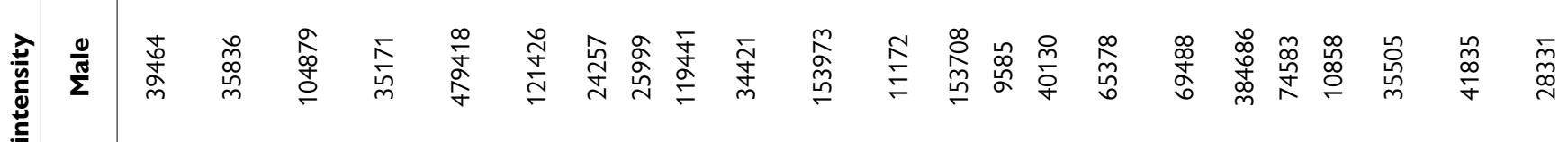

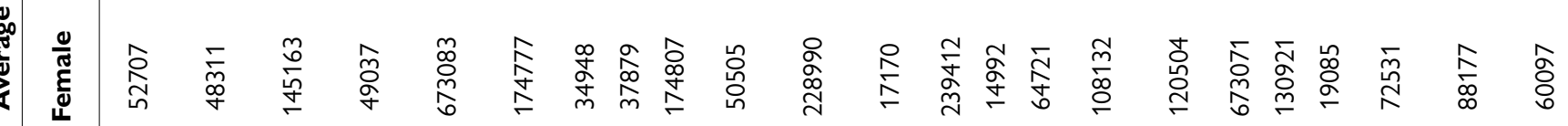

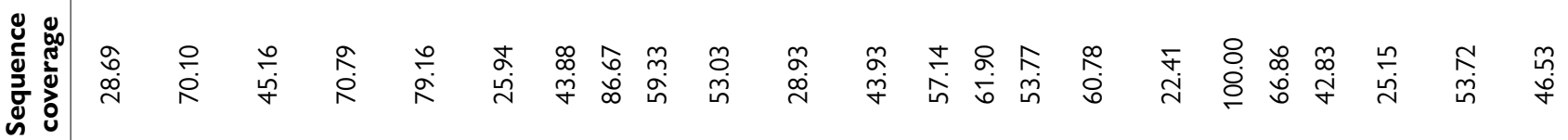

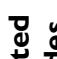

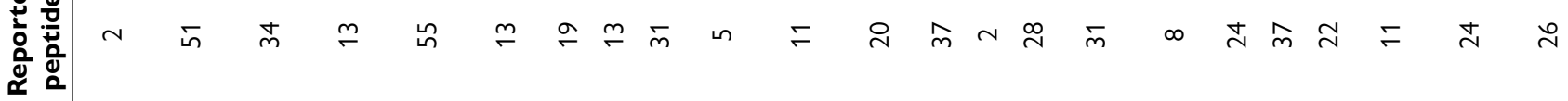

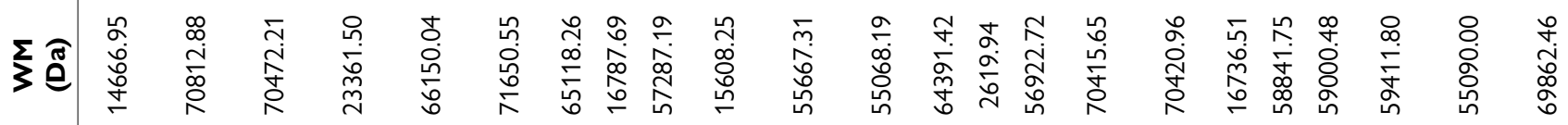

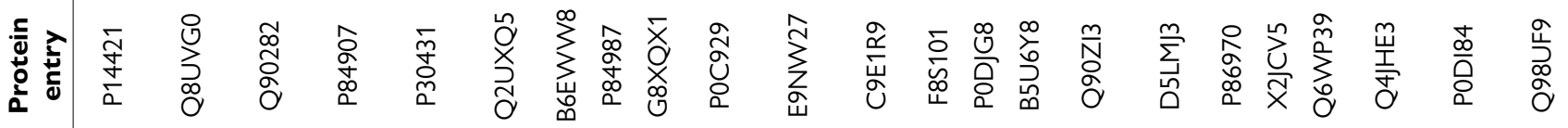

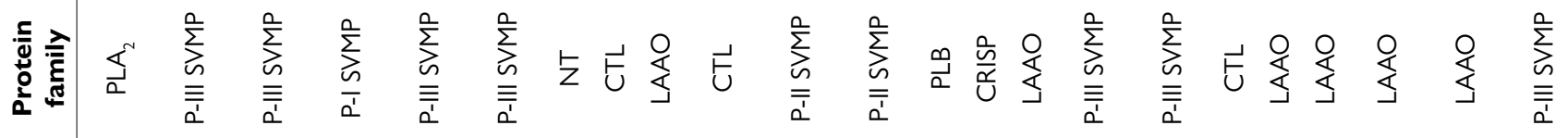

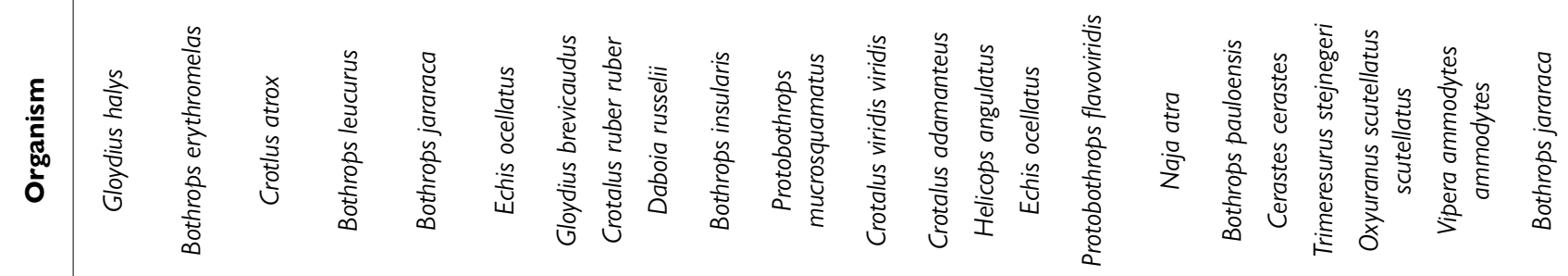

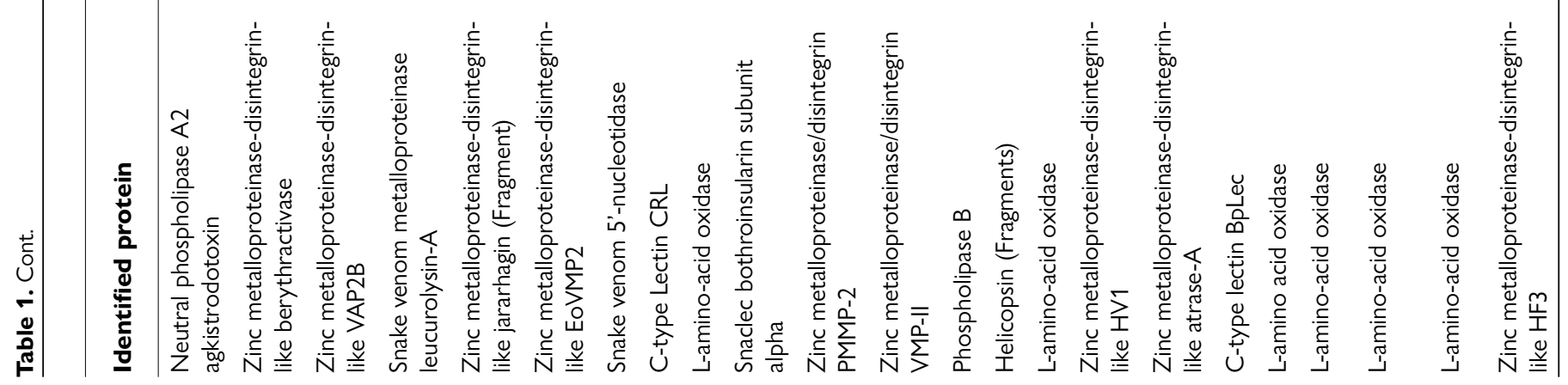




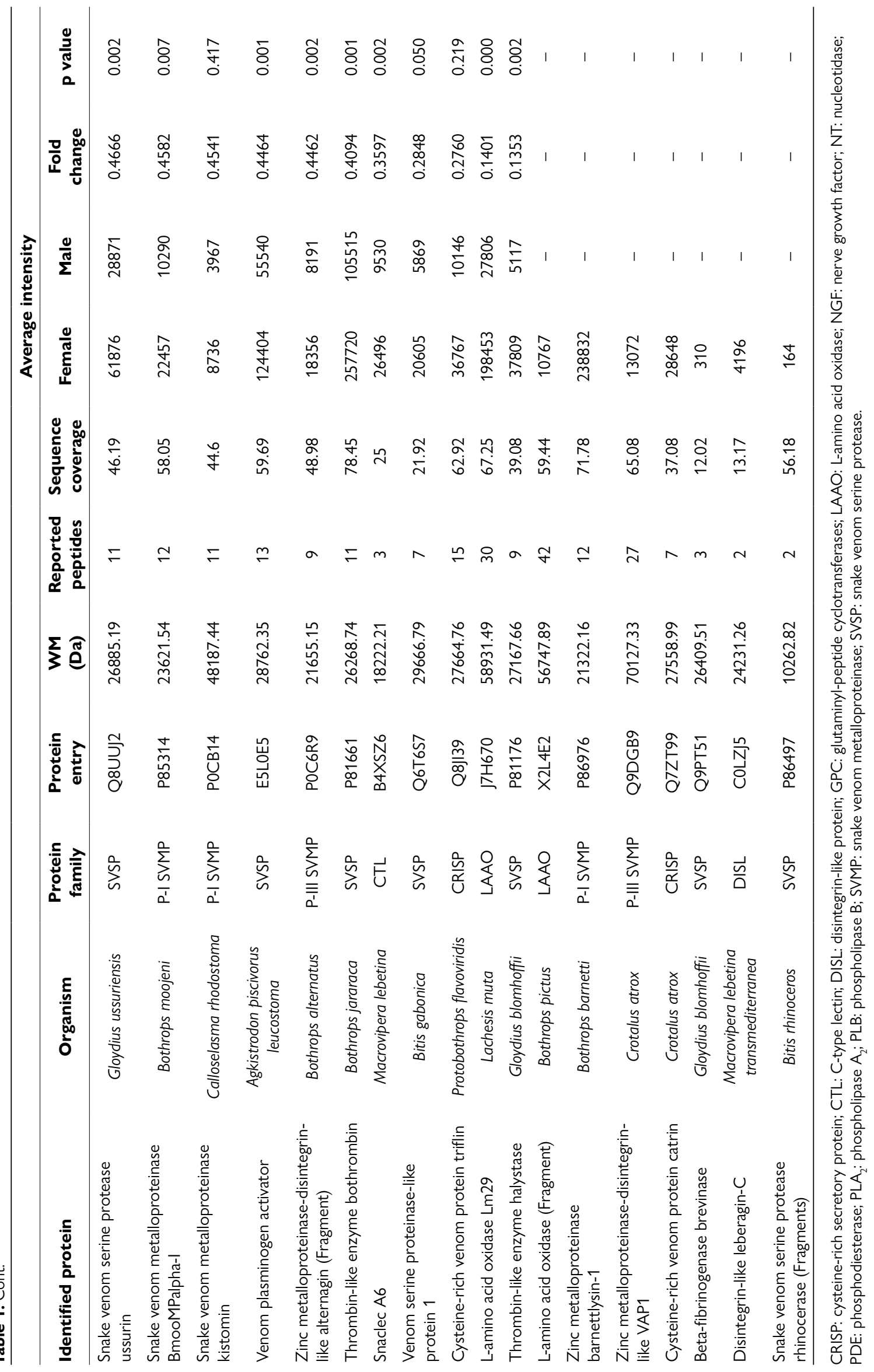


compounds in Bothrops venoms [32,64-66]. The unique proteins identified in the female venom were one LAAO, one P-I SVMP, one P-III SVMPs, one DISL, one CRISP, and two fragments of SVSPs. The Bpic-LAAO is a high weight protein of $65 \mathrm{kDa}$ that causes edema and inhibition of platelet aggregation [67]; the P-I SVMP (barnettlysin-1) is non-hemorrhagic and is known to cleave many substrates, including fibrin(ogen), but not collagen [68]; VAP-1 is a P-III SVMP related to hemorrhagic activity, but is unable to cleave collagen [69]; leberagin-C is a DISL that inhibits platelet aggregation [70]; the exclusive CRISP found in the female venom was catrin-2, which weakly blocks muscle contraction induced by $\mathrm{K}^{+}$and $\mathrm{Ca}^{2+}$ channels [71].

Sousa et al. [30] examined the venom composition of B. atrox according to their habitats and the proteomics analyses showed some differences in comparison to our study, such as the presence of hyaluronidases, which were not identified in this work. It is interesting to note that the relative percentages of LAAOs and SVSPs obtained by our group by MS analysis were higher than the aforementioned study, $16 \%$ in comparison to $~ 9 \%$ for LAAOs, and $21 \%$ in comparison to $10 \%$ to $14 \%$ for SVSPs, respectively. Another study indicates higher percentages of SVMPs than found here and have not detected any PLB [60].

\section{Functional analysis}

Proteolytic activities over casein and collagen did not show statistical difference between female and male pools, although some individual variations were observed. For caseinolytic activity (Figure 3A), only $\mathrm{Ba} 4$ and $\mathrm{Ba} 6$ showed statistical difference. As for collagenolytic activity (Figure 3B), individual variability was more evident. Caseinolytic activity may be associated with SVMP and SVSP, since casein is a substrate degraded by these families of proteins $[72,73]$ and, in this study, neither of these two protein families differed between the pools analyzed by MS (Figure 2).

LAAOs have the ability to induce or inhibit platelet aggregation, in addition to promoting hemorrhage, hemolysis, the appearance of edema, and other biological activities [74-76]. The percentage of LAAOs found in female venom pool analyzed by MS was slightly higher than for males. However, male venom pool showed higher activity compared to the female pool (Figure 3C). Although contrasting, the same behavior was observed in B. moojeni [34]. Similar to collagenolytic activity, LAAO activity differed individually.

$\mathrm{PLA}_{2}$ activity (Figure 3D) of B. atrox venom showed a strong individual variation, but, overall, the venom of males presented higher activity than female venoms. This was also reflected in the pools: male pool had a higher activity than female pool. Similar results were also observed in other species, like $B$. jararaca and $B$. moojeni $[34,77]$. This result was corroborated by mass spectrometry identification, in which a higher percentage of PLA was found in the male pool. In Viperidae, the $\mathrm{PLA}_{2} \mathrm{~s}$ found in snake venoms have been divided into two groups: with catalytic activity (Asp49 - D49) and without catalytic activity (Lys49 K49). The substitution of the amino acid residue Asp-49 for
Lys-49 consequently causes loss of calcium binding, primordial for its enzymatic activity [78].

In MCD analysis (Figure 3E), female venoms showed very similar activity among them, as well as the pool. As for males, Ba8 showed the highest activity, comparable to females, while the others presented much lower activity in comparison to females. The MCD is most likely attributed to procoagulant SVMPs and SVSPs, relating to activation of prothrombin and factor $\mathrm{X}$ of the clotting cascade $[79,80]$. Despite similarities in abundance between the groups, the female pool showed, altogether, slightly more SVSP than male pool in proteomic analysis. Besides, female venom pool had slightly higher amount of thrombin-like than the male pool (11.0\% and $10.6 \%$, respectively) (Figure 2, Table 1 and Additional file 3). Also, if we consider that 112 proteins were identified in the mass spectrometry of $B$. atrox snake venoms used in this study and that each protein-protein interaction responds differently depending on the compounds involved $[16,17]$, this difference may also be attributed to the synergy between protein families in local and systemic damage. It is important to highlight the limitations of the use of plasma without recalcification in this work because this may influence the time of clotting of each venom. Although it is known that SVMPs from the group A are not dependant of cofactors (including calcium) to activate prothrombin [81], a recent study [82] showed that the procoagulant effects of Bothrops genus snake venoms are highly dependant of calcium and that the dependency varies between populations. Although the results obtained herein show that, in the absence of calcium, the venom of females $B$. atrox is prone to be more coagulant, it is important to consider the role of calcium upon snake venom coagulopaties, even for independent calcium prothrombin activators [83], which may result in a misinterpretation of the relative toxicities.

Individual differences were observed in enzymatic activities, highlighting the importance of individual analysis when possible. Despite some individual differences, a pattern between the activities of females and males can be correlated, so, for in vivo tests, the pool was chosen for analysis. Galizio et al. [84] reinforce the importance of the individual analysis, but for ethical issues pools were used to reduce the number of animals utilized in the in vivo experiments.

MHD of male venoms was lower when compared to females ( 2.7 and $4.8 \mu \mathrm{g} /$ animal, respectively), indicating that female venom pool needs more than $43.8 \%$ of venom to generate the corresponding hemorrhagic halo to MHD, than male venom pool. Saldarriaga et al. [51] found $1.8 \mu \mathrm{g} / \mathrm{animal}$ as MHD for adult (3 years old) B. atrox, a minor dose than the one found in this work. Although considered adults, these snakes were younger than the ones in our work. Guércio et al. [24] analyzed the ontogenetic variation in the proteome of B. atrox and identified more P-III SVMPs in younger snakes than in adults, which could explain the higher hemorrhagic effects observed elsewhere [51]. The difference in MHD observed between female and male pools in our work may be attributed to the different abundance of P-III SVMPs identified in the venom pools. 
A

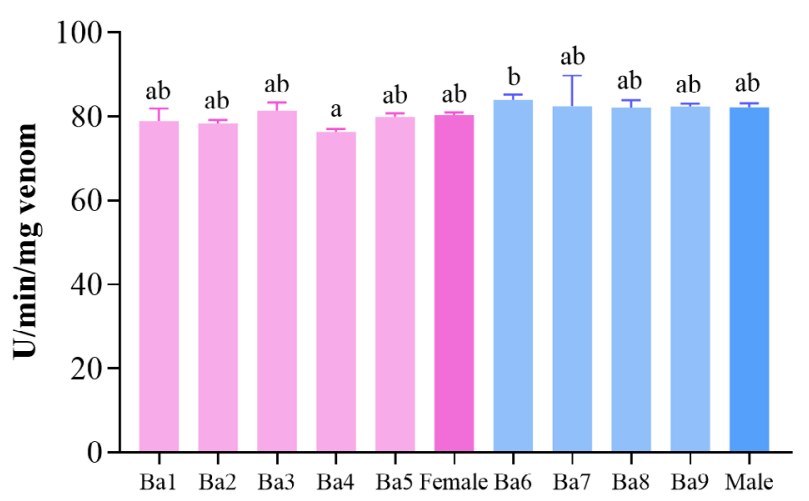

C

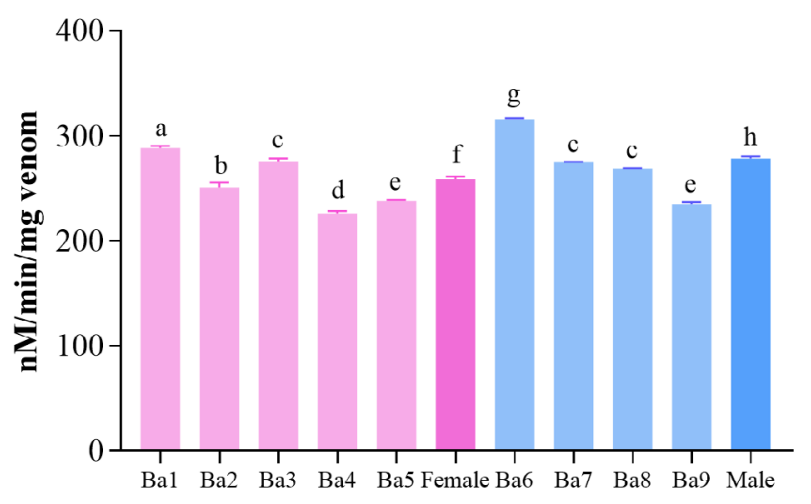

B

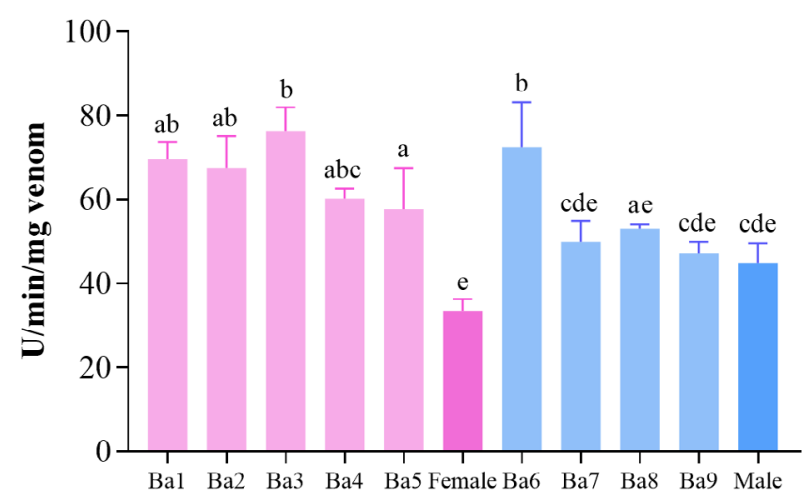

D

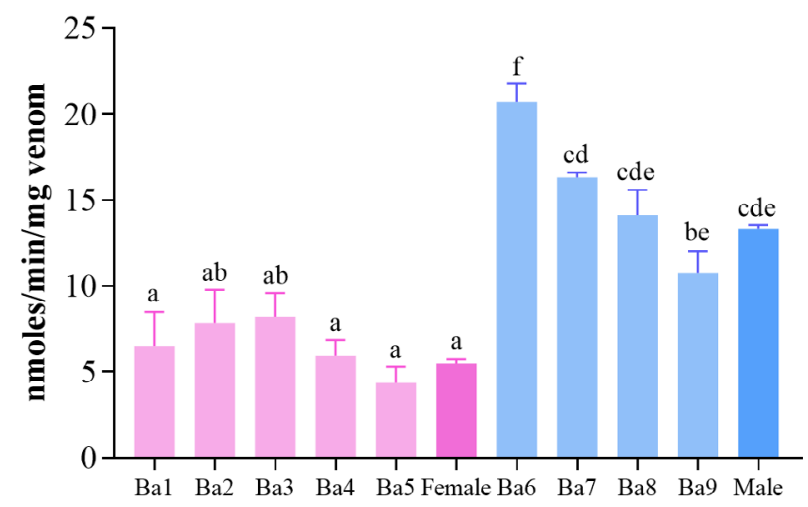

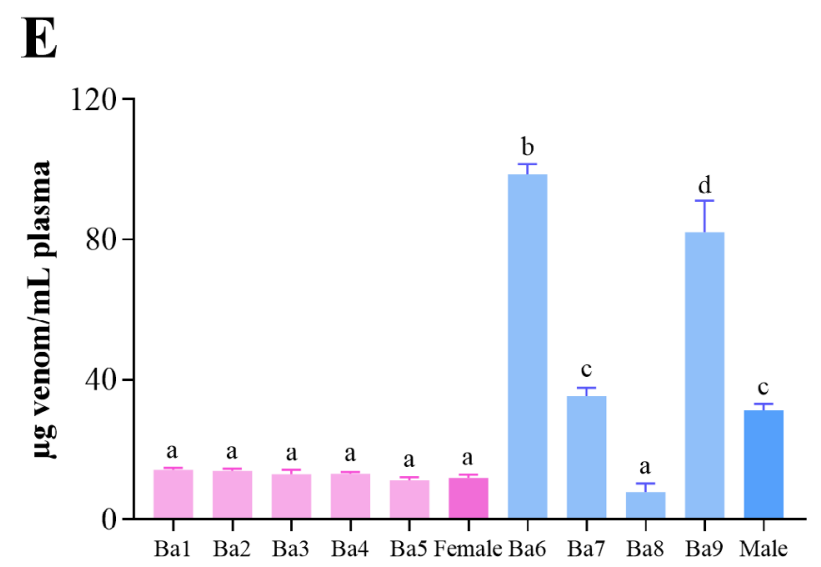

Figure 3. Enzymatic activities of $B$. atrox venom (individual and pool). The data were expressed as mean $\pm S D, n=3$. Different letters indicate statistical difference (ANOVA, $p$ < 0.05). (A) Caseinolytic activity; (B) collagenolytic activity; (C) LAAO activity; (D) PLA activity; (E) MCD.

$\mathrm{LD}_{50}$ of female venom pool of $B$. atrox $(104.3 \mu \mathrm{g} / \mathrm{animal}$; CI: $73.3-151.2 \mu \mathrm{g} / \mathrm{animal}$ ) was slightly lower than that of the male (118.4 $\mu \mathrm{g} / \mathrm{animal}$; CI: 87.2-164.8 $\mu \mathrm{g} / \mathrm{animal})$, but with no statistical difference. Although differences were observed in some activities, this is not reflected in the venom lethality. Saldarriaga et al. [47] found $81.4 \mu \mathrm{g} / \mathrm{mice}$ as $\mathrm{LD}_{50}$ for adult $B$. atrox, a minor dose than found in this work. Also, Sousa et al.
[30] compared the geographic variation of $B$. atrox and reported a lower $\mathrm{LD}_{50}$ than herein observed and suggested a correlation with the lower hemorrhagic activity. This is consistent with the results of the procoagulant and hemorrhagic activities, which are apparently related to the lethality of the venom $[85,86]$. Another study relates a lack of hemorrhagic activity associated with a higher lethality in Daboia russelii [87]. 
There was a marked difference between hemorrhagic and procoagulant activities between the venom of males and females, and these results may relate with the metabolic requirements of each sex. The metabolic rate of males and females is different, and it has been previously shown in viperids that females have a higher oxygen consumption, which is related to the animal's mass [88]. Since B. atrox is a species displaying sexual dimorphism, in which females are usually larger than males, it is possible that females have a higher energy demand due to their larger size, in addition to the need of extra energy reserved for reproduction [89].

Regarding MHD, the variation may have been caused by the relative abundance of proteins with hemorrhagic activity, which is slightly lower in the female venom pool than in the male venom pool. This activity may be under the influence of other proteins and/or the synergistic effect of other compounds in the venom.

\section{Immunorecognition by antibothropic serum}

The antivenom produced at Butantan Institute is composed by antibodies raised in horses, using a mixture of B. jararaca (50\%),
B. jararacussu (12.5\%), B. alternatus (12.5\%), B. moojeni (12.5\%) and $B$. neuwiedi complex (12.5\%) venom. Although B. atrox is not included in the venom pool used to produce the antivenom, it seems to have a moderate reaction with the serum (Figure 4).

Overall, the antibothropic serum produced at Butantan Institute recognized all venoms similarly, especially the ones with higher and lower molecular weights (Figure 4). Curiously, the band between 20 and $25 \mathrm{kDa}$ were not well recognized by the serum in all groups, although it's very strong in the gel (Figure 1B). Analyzing the MS (Table 1 and Additional file 3), it is concluded that this band probably represents a PI-SVMP. Other studies concerning $B$. atrox venom that also tested the immunerecognition using the antibothropic serum produced at Butantan Institute, showed that this reaction is not as strong as with other species' venom; and geographic variation seems to have great influence in the reactivity of the venoms to the antivenom [51,58,62,90]. Moreover, Sousa and colleagues [30] found striking differences in the neutralization of in vivo activities of $B$. atrox venoms from different habitats, regardless of the similarity in the reaction observed by ELISA.

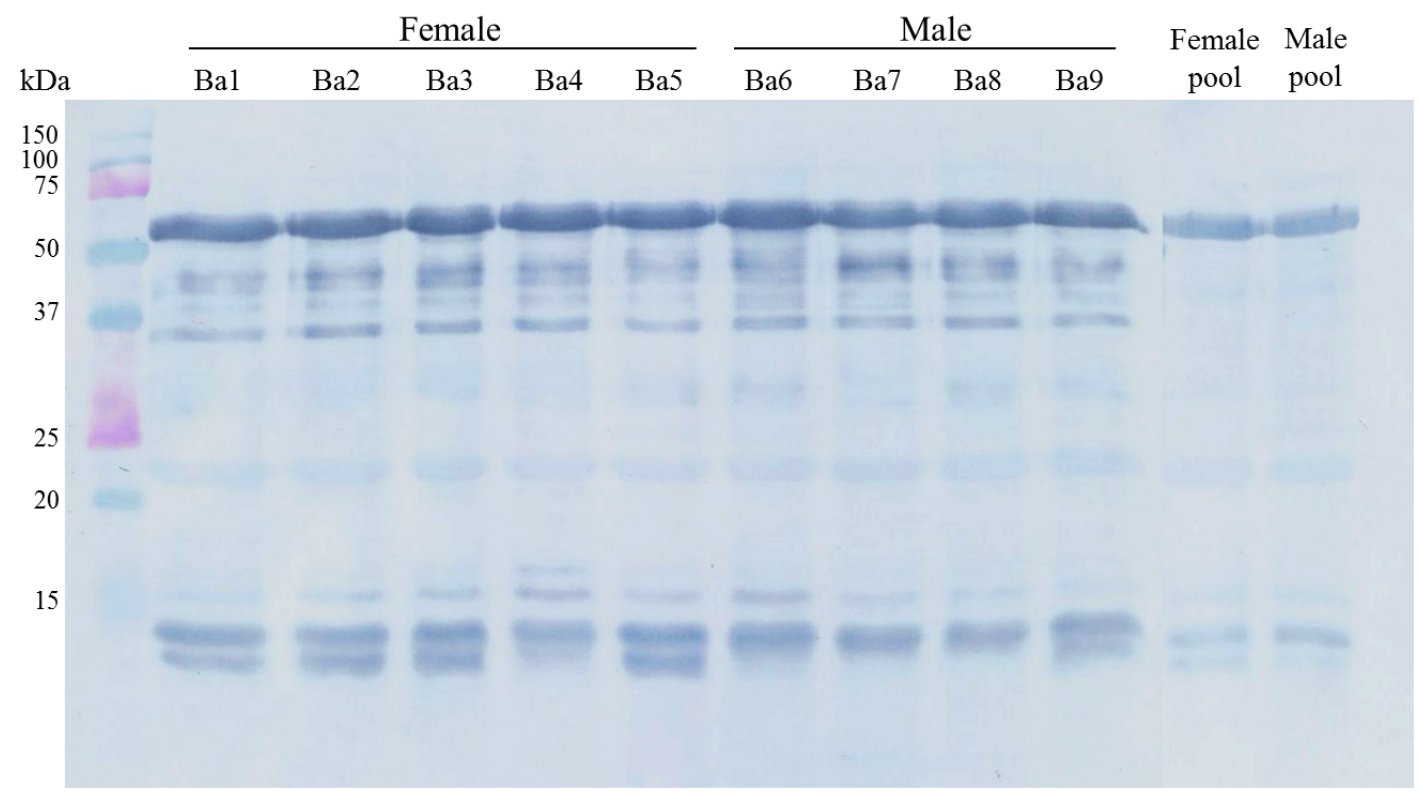

Figure 4. Immune interaction between the proteins of B. atrox venoms and the antibothropic serum by western blotting. Individual female (Ba1 to Ba5), male (Ba6 to Ba9) and respective pools were used and are indicated above the gel.

\section{Conclusion}

Several studies have shown that $B$. atrox venom may have variability in their biological activity and protein composition. This work extends the outlook regarding this variability, showing that female and male venoms of $B$. atrox siblings, under the same controlled environmental conditions, present subtle differences in their composition and activities. Moreover, it was observed individual variability in the characteristics of venoms, indicating that, in addition to aspects such as, geographical location, ontogeny, sex and diet, there are several unknown factors that result in the venom plasticity and physiological effects.

\section{Abbreviations}

1-DE: one dimensional electrophoresis; ADH: alcohol dehydrogenase; ANOVA: analysis of variance; BSA: bovine serum albumin; CEUAIB: Comissão de Ética no Uso de Animais do Instituto Butantan (Ethical Committee for the Use of Animals of Butantan Institute); CI: confidence interval; CONCEA: Conselho Nacional de Controle de Experimentação Animal (Brazilian Council of Animal Experimentation Control); CRISP: cysteine-rich secretory protein; CTL: C-type lectin; DISL: disintegrin-like protein; DTT: dithiothreitol; GPC: glutaminyl-peptide cyclotransferases; IAA: iodoacetamide; 
kDa: kilodalton; LAAO: L-amino acid oxidase; LC-MS/MS: liquid chromatography-mass spectrometry/mass spectrometry; $\mathrm{LD}_{50}$ : lethal dose 50\%; MCD: minimum coagulant dose; $\mathrm{MHD}$ : minimum hemorrhagic dose; NOBA: 4-nitro-3-octanoyloxybenzoic acid; NT: nucleotidase; PDE: phosphodiesterase; PLA 2 : phospholipase $\mathrm{A}_{2}$; PLB: phospholipase B; PVDF: polyvinylidene difluoride; RP-HPLC: reverse-phase high performance liquid chromatography; RP-UPLC: reverse-phase ultra performance liquid chromatography; SD: standard deviation; SVMP: snake venom metalloproteinase; SVSP: snake venom serine proteinase; TBS: Tris-buffered-saline; TCA: trichloroacetic acid; TFA: trifluoroacetic acid.

\section{Availability of data and materials}

All data generated or analyzed during this study are included in this article.

\section{Funding}

This study was financially supported by the Coordination for the Improvement of Higher Education Personnel (CAPES), the National Council for Scientific and Technological Development (CNPq) and the São Paulo Research Foundation (FAPESP projects: 2017/16908-2, 2017/20106-9, 2017/01890-0 and 2018/25786-0).

\section{Competing interests}

The authors declare that they have no competing interests.

\section{Authors' contributions}

$\mathrm{DMH}$ and LJT contributed equally to this work. CABT, KMZ and AMTA conceived and designed the experiments. AKT conducted mass spectrometry experiments and analysis. $\mathrm{DMH}$, LJT, CABT, CSS, CFBR, WSA, NCG, EOVL, VKK and IBF performed the biochemical and biological experiments and analysis. SSS, KFG, KMZ and AMTA contributed with reagents/ materials/analysis tools. SSS and KGF were responsible for the management of animals. DMH, LJT, JDGM, KMZ and AMTA participated in the design and interpretation of the data. $\mathrm{DMH}$, LJT, CABT, JDGM, KMZ and AMTA wrote the manuscript. All authors have read and contributed to the revision of this article.

\section{Ethics approval}

All experiments involving mice and snakes were approved by the Ethical Committee for the Use of Animals of Butantan Institute (CEUAIB), São Paulo, Brazil, protocol identification number $1375 / 15$ and $1296 / 14$, respectively. In addition, the experiments were in agreement with the Ethical Principles in Animal Research adopted by the Brazilian Council of Animal Experimentation Control (CONCEA).

\section{Consent for publication}

Not applicable.

\section{Supplementary material}

The following online material is available for this article:

Additional file 1. Individual information of snakes used in this work.

Additional file 2. Data of the processed spectra.

Additional file 3. Protein identification by LC-MS/MS.

\section{References}

1. Gutiérrez JM, Calvete JJ, Habib AG, Harrison RA, Williams DJ, Warrell DA. Snakebite envenoming. Nat Rev Dis Primers. 2017 Sep 14;3(1):2017.63. doi: 10.1038/nrdp.2017.63.

2. Chippaux JD. Snakebite envenomation turns again into a neglected tropical disease! J Venom Anim Toxinas Incl Trop Dis. 2017 Ago 8;23:38. doi: 10.1186/s40409-017-0127-6.

3. Chippaux JP. Snake-bites: appraisal of the global situation. Bull World Health Organ. 1998;76(5):515-24.

4. Kasturiratne A, Wickremasinghe AR, Silva N, Gunawardena NK, Pathmeswaran A, Premaratna R, et al. The global burden of snakebite: a literature analysis and modelling based on regional estimates of envenoming and deaths. PLoS Med. 2008 Nov 4;5(11):e218. doi: 10.1371/journal. pmed.0050218.

5. Chippaux JP. Epidemiology of envenomations by terrestrial venomous animals in Brazil based on case reporting: from obvious facts to contingencies. J Venom Anim Toxins Incl Trop Dis. 2015 May 13;21:13. doi: 10.1186/s40409-015-0011-1.

6. Bochner R, Souza CM. Divergences between the Brazilian national information systems for recording deaths from venomous animals. J Venom Anim Toxins Incl Trop Dis. 2019;25: e143018. doi: 10.1590/1678-9199_ JVATITD-1430-18.

7. Warrell, DA. Snakebites in Central and South America: epidemiology, clinical features, and clinical management. In: Campbell JA, Lamar WW, editors. The venomous reptiles of the western hemisphere. Vol 2. New York: Cornell University Press; 2004. p. 709-62.

8. Melgarejo AR. Serpentes peçonhentas do Brasil. In: Cardoso JL, França FO, Wen FH, Malaque CM, Haddad V Jr, editors. Animais peçonhentos no Brasil: biologia, clínica e terapêutica dos acidentes. São Paulo: Sarvier; 2003. p. 33-61. Portuguese.

9. Oliveira ME, Martins M. When and where to find a pitviper: activity patterns and habitat use of the lanceheade, Bothrops atrox, in Central Amazonia, Brazil. Herpetol Nat Hist. 2001;8(2):101-10.

10. Sasa M, Wasko DK, Lamar WW. Natural history of the terciopelo Bothrops asper (Serpentes: Viperidae) in Costa Rica. Toxicon. 2009 Dec;54(7):904-22. doi: 10.1016/j.toxicon.2009.06.024.

11. Martins M, Marques OA, Sazima I. Ecological and phylogenetic correlates of feeding habits in Neotropical pitvipers of the genus Bothrops. In: Schuett GW, Höggren M, Douglas ME, Greene HW, editors. Biology of the vipers. Eagle Mountain: Eagle Mountain Publishing; 2002. p. 307-28.

12. Bisneto PF, Kaefer IL. Reproductive and feeding biology of the common lancehead Bothrops atrox (Serpentes, Viperidae) from central and southwestern Brazilian Amazonia. Acta Amaz. 2019 May 6;49(2):10513. doi: $10.1590 / 1809-4392201802371$.

13. Pardal PP, Souza SM, Monteiro MR, Fan HW, Cardoso JL, França FO, et al. Clinical trial of two antivenoms for the treatment of Bothrops and Lachesis bites in the north eastern Amazon region of Brazil. Trans R Soc Trop Med Hyg. 2004;98(1):28-42. doi: 10.1016/S0035-9203(03)00005-1.

14. Santos Barreto GN, Oliveira SS, Anjos IV, Chalkidis HM, Mourão RH, Moura-da-Silva AM, et al. Experimental Bothrops atrox envenomation: Efficacy of antivenom therapy and the combination of Bothrops antivenom with dexamethasone. PLoS NegI Trop Dis. 2017 Mar 17;11(3):e0005458. doi: 10.1371/journal.pntd.0005458.

15. Amaral CF, Rezende NA, Silva OA, Ribeiro MM, Magalhães RA, Reis RJ et al. Insuficiência renal aguda secundária a acidentes ofídicos botrópico 
e crotálico: análise de 63 casos. Rev Inst Med Trop S Paulo. 1986 JulAug;28(4):220-7. Portuguese. doi: 10.1590/S0036-46651986000400003.

16. Doley R, Kini RM. Protein complexes in snake venom. Cell Mol Life Sci. 2009 Sep;66(17):2851-71. doi: 10.1007/s00018-009-0050-2.

17. Vonk FJ, Jackson K, Doley R, Madaras F, Mirtschin PJ, Vidal N. Snake venom: from fieldwork to the clinic: recent insights into snake biology, together with new technology allowing high-throughput screening of venom, bring new hope for drug discovery. BioEssays. 2011 Apr;33(4):269-79. doi: 10.1002/bies.201000117.

18. Markland FS. Snake venoms and the hemostatic system. Toxicon. 1998 Dec;36(12):1749-800. doi: 10.1016/S0041-0101(98)00126-3.

19. Chippaux JP, Williams V, White J. Snake venom variability: methods of study, results and interpretation. Toxicon. 1991;29(11):1279-303. doi: 10.1016/0041-0101(91)90116-9.

20. Zaqueo KD, Kayano AM, Domingos TF, Moura LA, Fuly AL, Silva SL, et al. BbrzSP-32, the first serine protease isolated from Bothrops brazili venom: purification and characterization. Comp Biochem Physiol A Mol Integr Physiol. 2016 May;195:15-25. doi: 10.1016/j.cbpa.2016.01.021.

21. McCleary RJ, Kini RM. Non-enzymatic proteins from snake venoms: a gold mine of pharmacological tools and drug leads. Toxicon. 2013 Feb;62:5674. doi: 10.1016/j.toxicon.2012.09.008.

22. McCleary RJ, Sridharan S, Dunstan NL, Mirtschin PJ, Kini RM. Proteomic comparisons of venoms of long-term captive and recently wild-caught Eastern brown snakes (Pseudonaja textilis) indicate venom does not change due to captivity. J Proteomics. 2016 Jul 20;144:51-62. doi: 10.1016/j. jprot.2016.05.027.

23. Furtado MF, Maruyama M, Kamiguti AS, Antonio LC. Comparative study of nine Bothrops snake venoms from adult female snakes and their offspring. Toxicon. 1991;29(2):219-26. doi: 10.1016/0041-0101(91)90106-2.

24. Guércio RA, Shevchenko A, Shevchenko A, López-Lozano JL, Paba J, Sousa MV, et al. Ontogenetic variations in the venom proteome of the Amazonian snake Bothrops atrox. Proteome Sci. 2006 May 11;4:11. doi: 10.1186/1477-5956-4-11.

25. Santoro ML, Carmo T, Cunha BH, Alves AF, Zelanis A, Serrano SM, et al. Ontogenetic variation in biological activities of venoms from hybrids between Bothrops erythromelas and Bothrops neuwiedi snakes. PLoS One. 2015 Dec 19;10(12):e0145516. doi: 10.1371/journal.pone.0145516.

26. Daltry JC, Wuster W, Thorpe RS. Diet and snake venom evolution. Nature. 1996 Feb 8;379(6565):537-40. doi: 10.1038/379537a0.

27. Lariviere WR, Chesler EJ, Zhen L, Gang-Wei S, Ya-Ning C, Yao-Qing Y, et al. Correlations between edema and the immediate and prolonged painful consequences of inflammation: therapeutic implications? Sheng Li Xue Bao, 2005 Jun 25;57(3):278-88.

28. Williams $\vee$, White J. Variation in the composition of the venom from a single specimen of Pseudonaja textilis (common brown snake) over one year. Toxicon. 1992 Feb;30(2):202-6. doi: 10.1016/0041-0101(92)90473-I.

29. Massey DJ, Calvete JJ, Sánchez EE, Sanz L, Richards K, Curtis R, et al. Venom variability and envenoming severity outcomes of the Crotalus scutulatus scutulatus (Mojave rattlesnake) from Southern Arizona. J Proteomics. 2012 May 17;75(9):2576-87. doi: 10.1016/j.jprot.2012.02.035.

30. Sousa LF, Portes JA Jr, Nicolau CA, Bernardoni JL, Nishiyama MY Jr, Amazonas DR, et al. Functional proteomic analyses of Bothrops atrox venom reveals phenotypes associated with habitat variation in the Amazon. J Proteomics. 2017 Apr 21;159:32-46. doi: 10.1016/j.jprot.2017.03.003.

31. Cavinato RA, Remold H, Kipnis TL. Purification and variability in thrombinlike activity of Bothrops atrox venom from different geographic regions. Toxicon. 1998 Feb;36(2):257-67. doi: 10.1016/S0041-0101(97)00129-3.

32. Menezes MC, Furtado MF, Travaglia-Cardoso SR, Camargo AC, Serrano SM. Sex-based individual variation of snake venom proteome among eighteen Bothrops jararaca siblings. Toxicon. 2006 Mar;47(3):304-12. doi: 10.1016/j.toxicon.2005.11.007.

33. Pimenta DC, Prezoto BC, Konno K, Melo RL, Furtado MF, Camargo AC, et al. Mass spectrometric analysis of the individual variability of Bothrops jararaca venom peptide fraction. Evidence for sex-based variation among the bradykinin-potentiating peptides. Rapid Commun Mass Spectrom. 2007 Feb 22;21(6):1034-42. doi: 10.1002/rcm. 2931.
34. Amorim FG, Costa TR, Baiwir D, de Pauw E, Quinton L, Sampaio SV. Proteopeptidomic, functional and immunoreactivity characterization of Bothrops moojeni snake venom: influence of snake gender on venom composition. Toxins (Basel). 2018 Apr 26;10(5):177. doi: 10.3390/ toxins10050177.

35. Zelanis A, Menezes MC, Kitano ES, Liberato T, Tashima AK, Pinto AF, et al. Proteomic identification of gender molecular markers in Bothrops jararaca venom. J Proteomics. 2016 Apr 29;139:26-37. doi: 10.1016/j. jprot.2016.02.030.

36. Freitas-de-Sousa LA, Amazonas DR, Sousa LF, Sant'Anna SS, Nishiyama MY, Serrano SM, et al. Comparison of venoms from wild and long-term captive Bothrops atrox snakes and characterization of Batroxrhagin, the predominant class PIII metalloproteinase from the venom of this species. Biochimie. 2015 Nov;118:60-70. doi: 10.1016/j.biochi.2015.08.006.

37. Gonçalves-Machado L, Pla D, Sanz L, Jorge RJ, Leitão-De-Araújo M, Alves $M L$, et al. Combined venomics, venom gland transcriptomics, bioactivities, and antivenomics of two Bothrops jararaca populations from geographic isolated regions within the Brazilian Atlantic rainforest. J Proteomics. 2016 Mar 1;135:73-89. doi: 10.1016/j.jprot.2015.04.029.

38. Krüger NJ. The Bradford method for protein quantification. In: Walker JM, editor. The protein protocols handbook. 2nd ed. New Jersey: Humana Press; 2002. p. 15-21.

39. Laemmli UK. Cleavage of structural proteins during the assembly of the head of bacteriophage $T_{4}$. Nature. 1970 Aug 15;227(5259):680-5. doi: 10.1038/227680a0.

40. Distler U, Kuharev J, Navarro P, Levin Y, Schild H, Tenzer S. Drift timespecific collision energies enable deep-coverage data-independent acquuisition proteomics. Nat Methods. 2014 Feb;11(2):167-70. doi: 10.1038/nmeth.2767.

41. Morais-Zani K, Serino-Silva C, Galizio NC, Tasima LJ, Pagotto JF, Rocha $M M$, et al. Does the administration of pilocarpine prior to venom milking influence the composition of Micrurus corallinus venom? J Proteomics. 2018 Mar 1;174:17-27. doi: 10.1016/j.jprot.2017.12.010.

42. Pedroso AP, Souza AP, Dornellas AP, Oyama LM, Nascimento CM, Santos GM, et al. Intrauterine growth restriction programs the hypothalamus of adult male rats: integrated analysis of proteomic and metabolomic data. J Proteome Res. 2017 Mar 17;16(4):1515-25. doi: 10.1021/acs. jproteome.6b00923.

43. Silva JC, Gorenstein MV, Li G-Z, Vissers JP, Geromanos SJ. Absolute quantification of proteins by LCMSE: a virtue of parallel ms acquisition. Mol Cell Proteomics. 2006 Jan 1;5(1):144-56. doi: 10.1074/mcp.M500230MCP200.

44. Wang W-J, Huang T-F. Purification and characterization of a novel metalloproteinase, acurhagin, from Agkistrodon acutus venom. Thromb Haemost. 2002;87(4):641-50. doi: 10.1055/s-0037-1613061.

45. Váchová L, Maravcová J. Two microassays for determination of a wide range of proteolytic activities using Azocoll as substrate. Biochem Mol Biol Int. 1993 May 31;30(2):311-8.

46. Antunes TC, Yamashita KM, Barbaro KC, Saiki M, Santoro ML. Comparative analysis of newborn and adult Bothrops jararaca snake venoms. Toxicon. 2010 Dec;56(8):1443-58. doi: 10.1016/j.toxicon.2010.08.011.

47. Kishimoto M, Takahashi T. A spectrophotometric microplate assay for L-Amino Acid Oxidase. Anal Biochem. 2001 Nov 1;298(1):136-9. doi: 10.1006/abio.2001.5381.

48. Holzer M, Mackessy SP. An aqueous endpoint assay of snake venom phospholipase A . Toxicon. 1996 Oct;34(10):1149-55. doi: 10.1016/00410101(96)00057-8.

49. Theakston RD, Reid HA. Development of simple standard assay procedures for the characterization of snake venoms. Bull World Health Organ. 1983;61(6):949-56.

50. Moura VM, Sousa LA, Dos-Santos MC, Raposo JD, Lima AE, Oliveira RB, et al. Plants used to treat snakebites in Santarém, western Pará, Brazil: An assessment of their effectiveness in inhibiting hemorrhagic activity induced by Bothrops jararaca venom. J Ethnopharmacol. 2015 Feb 23;161:224-32. doi: 10.1016/j.jep.2014.12.020.

51. Saldarriaga MM, Otero R, Núñez V, Toro MF, Díaz A, Gutiérrez JM. Ontogenetic variability of Bothrops atrox and Bothrops asper snake venoms 
from Colombia. Toxicon. 2003 Sep;42(4):405-11. doi: 10.1016/S00410101(03)00171-5.

52. Finney DJ. Probit analysis. 3rd ed. Cambridge (England): Cambridge University Press; 1971.

53. Harlow E, Lane D. Antibodies: a laboratory manual. New York: Cold Spring Harbor Laboratory; 1988.

54. Lourenço A Jr, Creste CF, Barros LC, Santos LD, Pimenta DC, Barraviera $B$, et al. Individual venom profiling of Crotalus durissus terrificus specimens from a geographically limited region: crotamine assessment and captivity evaluation on the biological activities. Toxicon. 2013 Jul;69:75-81. doi: 10.1016/j.toxicon.2013.01.006.

55. Oliveira LA, Ferreira RS Jr, Barraviera B, Carvalho FC, Barros LC, Santos LD, et al. Crotalus durissus terrificus crotapotin naturally displays preferred positions for amino acid substitutions. J Venom Anim Toxins Incl Trop Dis. 2017 Nov 28;23:46. doi: 10.1186/s40409-017-0136-5.

56. Saad E, Barros LC, Biscola N, Pimenta DC, Barraviera SR, Barraviera B, et al. Intraspecific variation of biological activities in venoms from wild and captive Bothrops jararaca. J Toxicol Environ Health A. 2012 Aug 1;75(16-17):1081-90. doi: 10.1080/15287394.2012.697839.

57. Tasima LJ, Serino-Silva C, Hatakeyama DM, Nishiduka ES, Tashima AK, Sant'Anna SS, et al. Crotamine in Crotalus durissus: distribution according to subspecies and geographic origin, in captivity or nature. J Venom Anim Toxins Incl Trop Dis. 2020 Apr 6;26:e20190053. doi: 10.1590/1678-9199_ JVATITD-2019-0053.

58. Calvete JJ, Sanz L, Pérez A, Borges A, Vargas AM, Lomonte B, et al. Snake population venomics and antivenomics of Bothrops atrox: Paedomorphism along its transamazonian dispersal and implications of geographic venom variability on snakebite management. J Proteomics. 2011 Apr 1;74(4):51027. doi: 10.1016/j.jprot.2011.01.003.

59. Núñez $\mathrm{V}$, Cid P, Sanz L, de la Torre P, Angulo Y, Lomonte B, et al. Snake venomics and antivenomics of Bothrops atrox venoms from Colombia and the Amazon regions of Brazil, Perú and Ecuador suggest the occurrence of geographic variation of venom phenotype by a trend towards paedomorphism. J Proteomics. 2009 Aug 5;73(1):57-78. doi: 10.1016/j.jprot.2009.07.013.

60. Amazonas DR, Portes-Junior JA, Nishiyama MY Jr, Nicolau CA, Chalkidis HM, Mourão RH, et al. Molecular mechanisms underlying intraspecific variation in snake venom. J Proteomics. 2018 Jun 15;181:60-72. doi: 10.1016/j.jprot.2018.03.032.

61. Salazar AM, Rodriguez-Acosta A, Girón ME, Aguilar I, Guerrero B. A comparative analysis of the clotting and fibrinolytic activities of the snake venom (Bothrops atrox) from different geographical areas in Venezuela. Thromb Res. 2007 Jan 1;120(1):95-104. doi: 10.1016/j. thromres.2006.07.004.

62. Queiroz GP, Pessoa LA, Portaro FC, Furtado MF, Tambourgi DV. Interspecific variation in venom composition and toxicity of Brazilian snakes from Bothrops genus. Toxicon. 2008 Dec 15;52(8):842-51. doi: 10.1016/j.toxicon.2008.10.002.

63. López-Lozano JL, Sousa MV, Ricart CA, Chávez-Olortegui C, Sanchez EF, Muniz EG, et al. Ontogenetic variation of metalloproteinases and plasma coagulant activity in venoms of wild Bothrops atrox specimens from Amazonian rain forest. Toxicon. 2002 Jul;40(7):997-1006. doi: 10.1016/ S0041-0101(02)00096-X.

64. Gutiérrez JM, Lomonte B. Local tissue damage induced by Bothrops snake venoms. A review. Mem Inst Butantan. 1989 Dec;51(4):211-23.

65. Nahas L, Kamiguti AS, Barros MA. Thrombin-Like and Factor X-Activator components of Bothrops snake venoms. Thromb Haemost. 1979 Apr 23;41(2):314-28. doi: 10.1055/s-0038-1646781.

66. Soares AM, Fontes MR, Giglio JR. Phospholipase $A_{2}$ Myotoxins from Bothrops snake venoms: structure-function relationship. Curr Org Chem. 2004;8(17):1677-90. doi: 10.2174/1385272043369610.

67. Lazo F, Vivas-Ruiz DE, Sandoval GA, Rodríguez EF, Kozlova EE, CostalOliveira F, et al. Biochemical, biological and molecular characterization of an L-Amino acid oxidase (LAAO) purified from Bothrops pictus Peruvian snake venom. Toxicon. 2017 Dec 1;139:74-86. doi: 10.1016/j.toxicon.2017.10.001.
68. Sanchez EF, Richardson M, Gremski LH, Veiga SS, Yarleque A, Niland S, et al. A novel fibrinolytic metalloproteinase, barnettlysin-I from Bothrops barnetti (barnett's pitviper) snake venom with anti-platelet properties. Biochim Biophys Acta Gen Subj. 2016 Mar;1860(3):542-56. doi: 10.1016/j. bbagen.2015.12.021.

69. Kikushima E, Nakamura S, Oshima Y, Shibuya T, Miao JY, Hayashi H, et al. Hemorrhagic activity of the vascular apoptosis-inducing proteins VAP1 and VAP2 from Crotalus atrox. Toxicon. 2008 Sep 15;52(4):589-93. doi: 10.1016/j.toxicon.2008.06.027.

70. Limam I, Bazaa A, Srairi-Abid N, Taboubi S, Jebali J, Zouari-Kessentini $\mathrm{R}$, et al. Leberagin-C, A disintegrin-like/cysteine-rich protein from Macrovipera lebetina transmediterranea venom, inhibits alphavbeta integrin-mediated cell adhesion. Matrix Biol. 2010 Mar;29(2):117-26. doi: 10.1016/j.matbio.2009.09.009.

71. Calvete JJ, Fasoli E, Sanz L, Boschetti E, Righetti PG. Exploring the venom proteome of the Western Diamondback Rattlesnake, Crotalus atrox, via Snake Venomics and Combinatorial Peptide Ligand Library Approaches. J Proteome Res. 2009 Apr 17;8(6):3055-67. doi: 10.1021/pr900249q.

72. Serrano SM, Maroun RC. Snake venom serine proteinases: sequence homology vs. substrate specificity, a paradox to be solved. Toxicon. 2005 Apr;45(8):1115-32. doi: 10.1016/j.toxicon.2005.02.020.

73. Fox JW, Serrano SM. Timeline of key events in snake venom metalloproteinase research. J Proteomics. 2009 Jan 20;72(2):200-9. doi: 10.1016/j.jprot.2009.01.015.

74. Izidoro LF, Sobrinho JC, Mendes MM, Costa TR, Grabner AN, Rodrigues $V M$, et al. Snake venom L-amino acid oxidases: trends in pharmacology and biochemistry. BioMed Res Int. 2014 Mar 12;2014:196754. doi: 10.1155/2014/196754.

75. Bordon KC, Wiezel GA, Cabral H, Arantes EC. Bordonein-L, a new $\mathrm{L}$-amino acid oxidase from Crotalus durissus terrificus snake venom: isolation, preliminary characterization and enzyme stability. J Venom Anim Toxins Incl Trop Dis. 2015 Aug 13;21:26. doi: 10.1186/s40409-015-0025-8.

76. Naumann GB, Silva LF, Silva L, Faria G, Richardson M, Evangelista K, et al. Cytotoxicity and inhibition of platelet aggregation caused by an L-amino acid oxidase from Bothrops leucurus venom. Biochim Biophys Acta Gen Subj. 2011 Jul;1810(7):683-94. doi: 10.1016/j.bbagen.2011.04.003.

77. Furtado MF, Travaglia-Cardoso SR, Rocha MM. Sexual Dimorphism in Venom of Bothrops jararaca (Serpentes: Viperidae). Toxicon. $2006 \mathrm{Sep}$ 15;48(4):401-10. doi: 10.1016/j.toxicon.2006.06.005.

78. Kini RM. Excitement ahead: structure, function and mechanism of snake venom phospholipase $A_{2}$ enzymes. Toxicon. 2003 Nov 30;42(8):827-40. doi: 10.1016/j.toxicon.2003.11.002.

79. Kini RM. Serine proteases affecting blood coagulation and fibrinolysis from snake venoms. Pathophysiol Haemost Thromb. 2005;34(4-5):200-4. doi: $10.1159 / 000092424$.

80. Kini RM, Koh CY. Metalloproteases affecting blood coagulation, fibrinolysis and platelet aggregation from snake venoms: definition and nomenclature of interaction sites. Toxins. 2016 Sep 29;8(10):284. doi: 10.3390/toxins8100284.

81. Kini RM, Rao VS, Joseph JS. Procoagulant proteins froms snake venoms. Haemostasis. 2001;31(3-6):218-24. doi: 10.1159/000048066.

82. Sousa LF, Zdenek CN, Dobson JS, op den Brouw B, Coimbra FC, Gillett $A$, et al. Coagulotoxicity of Bothrops (lancehead pit-vipers) venoms from Brazil: differential biochemistry and antivenom efficacy resulting from prey-driven venom variation. Toxins. 2018 Oct 11;10(10):411. doi: 10.3390/ toxins10100411.

83. Rogalski A, Soerensen C, op den Brown B, Lister C, Dashevsky D, Arbuckle K, et al. Differential procoagulant effects of saw-scaled viper (Serpentes: Viperidae: Echis) snake venoms on human plasma and the narrow taxonomic ranges of antivenom efficacies. Toxicol Lett. $2017 \mathrm{Oct}$ 5;280:159-70. doi: 10.1016/j.toxlet.2017.08.020.

84. Galizio NC, Serino-Silva C, Stuginski DR, Abreu PA, Sant'Anna SS, Grego $\mathrm{KF}$, et al. Compositional and functional investigation of individual and pooled venoms from long-term captive and recently wild-caught Bothrops jararaca snakes. J Proteomics. 2018 Aug 30;186:56-70. doi: 10.1016/j. jprot.2018.07.007. 
85. Ferreira ML, Moura-da-Silva AM, França FO, Cardoso JL, Mota I. Toxic activities of venoms from nine Bothrops species and their correlation with lethality and necrosis. Toxicon. 1992 Dec;30(12):1603-8. doi: 10.1016/0041-0101(92)90032-z.

86. Mackessy SP, Leroy J, Mociño-Deloya E, Setser K, Bryson RW, Saviola AJ. Venom Ontogeny in the Mexican lance-headed rattlesnake (Crotalus polystictus). Toxins. 2018 Jul 3;10(7):271. doi: 10.3390/toxins10070271.

87. Faisal T, Tan KY, Sim SM, Quraishi N, Tan NH, Tan CH. Proteomics, functional characterization and antivenom neutralization of the venom of Pakistani Russell's viper (Daboia russelii) from the wild. J Proteomics. 2018 Jul 15;183:1-13. doi: 10.1016/j.jprot.2018.05.003.
88. Beaupre SJ, Duvall D. Variation in oxygen consumption of the western diamondback rattlesnake (Crotalus atrox): implications for sexual size dimorphism. J Comp Physiol B. 1998 Oct;168:497-506. doi: 10.1007/ s003600050170.

89. Dugan EA, Hayes WK. Diet and feeding ecology of the red diamond rattlesnake, Crotalus ruber (Serpentes: Viperidae). Herpetologica. 2012 Jun 1;68(2):203-17. doi: 10.1655/HERPETOLOGICA-D-11-00008.1.

90. Bogarín G, Morais JF, Yamaguchi IK, Stephano MA, Marcelino JR, Nishikawa AK, et al. Neutralization of crotaline snake venoms from Central and South America by antivenoms produced in Brazil and Costa Rica. Toxicon. 2000 Oct;38(10):1429-41. doi: 10.1016/S0041-0101(99)00236-6. 